\title{
POLITENESS STRATEGIES IN RESPONSE TO REQUEST IN BRITISH AND PERSIAN FAMILY DISCOURSE
}

\author{
Neda Kameh Khosh \\ People's Friendship University of Russia, Russian Federation, kamekh_khosh_n@pfur.ru
}

\begin{abstract}
Being successful in intercultural communication relies strongly on understanding of communicative purposes of interlocutors and pragmatic meaning of their utterances. Established on numerous cross-cultural studies, politeness is a culture-specific phenomenon despite its universal nature and understanding of politeness as well as norms of politeness vary across different cultures (Blum-Kulka 1989 \&1992, Hickey \& Stewart 2005, Larina 2008 \& 2015, Locher \& Larina 2019, Mugford 2020, Pizziconi 2003, Sifianou 1992, Watts 2003, Watts \& Ide \& Ehlich 2005]. The aim of the present study is focusing on the speech act of response to request which is regularly taken place in everyday interactions and analyzing the norms and strategies of politeness in British and Persian contexts as well as explaining them through cultural differences. The material for the study was collected from a discourse completion test (DCT) responded by 112 British and Persian objects with our ethnographic observations. The analysis was performed with drawing on (im)politeness theory, speech act theory, cross-cultural pragmatic and discourse analysis, research on identity construction and the effect of politeness on communicative styles. The findings demonstrate that in British culture, the communicative styles in asymmetrical top-down (parents to children) and bottom-up (children to parents) contexts are egalitarian and children respond to requests of their parents and parents respond to requests of their children equally. This fact confirms a low power distance in British culture. By contrast, in Persian society, the communicative styles explicate a number of significant distinctions in top-down (parents to children) and bottom-up (children to parents) contexts which is due to an extensive index of power distance in Persian society. The paper reveals that the knowledge of cultural norms and communicative differences in various contexts is crucial for the second language acquisition and development of pragmatic competence of second language learners. Indeed, it is essential for understanding and successful intercultural communication.
\end{abstract}

Keywords: Politeness, impoliteness, communicative styles, interpersonal interactions, norms of politeness, pragmatic competence, family setting, Persian communicative culture, British communicative culture.

\section{Acknowledgement:}

The publication has been prepared with the support of the "RUDN University Program 5-100".

\section{INTRODUCTION}

Politeness, in Geoffrey Leech's perspective, is defined as "Communicative Altruism" (Leech, 2014, p. 3). Established on his comprehension of politeness in this broad meaning, politeness is a form of communicative behavior discovered very commonly in human languages and across human cultures. In fact, politeness is explained as a universal phenomenon which occurs in human society. Leech argues that being polite means to communicate or behave in such a way which results in giving benefit or value not to 
yourself but to another person(s) particularly the person(s) you are making conversation with (ibid. 4). He clarifies that when he points to politeness as communicative altruism, the altruistic sense transferred through communication should not be considered equal with altruism in its genuine meaning, where someone behaves or says something generously for the sake of some other person(s) in order to extend an assisting hand to them (Leech, 2014, p. 4).

Numerous difficulties in making communication descend from this fact that people do not only utter in distinctive languages, but also, they apply languages in different approaches based on particular social and linguistic values and norms as well as socio-cultural principles (Larina, 2015, Wierzbicka, 2003). The problem is brought into light with this fact that the notions of politeness and imposition differ across cultures. As a consequence, culture-specific communicative strategies impose a distinctive selection of language means used in the same situations. People who come from distinctive cultures do not constantly make opinions shared as to what is polite and what is not polite. In fact, the similar verbal or non-verbal act which is comprehended polite in one culture may be understood as a disproportionate or even perfectly disrespectful act in another culture. As stated by Watts (2003), the lexemes polite and politeness may have dissimilarities in meaning and their linked connotations among cultures (Watts, 2003, p. 14). He also insists on this notion that people's comprehension of politeness and polite behavior differ between people and circumstances. From his point of view, politeness is an evaluation process which is structured in a subjective approach (ibid. 14). When people tend to be polite in another culture, they need to master skills with which they could apply culture-specific strategies in that culture. These strategies might have minor or major dissimilarities with the same strategies in their own culture. Therefore, people have to rectify their verbal and non-verbal behavior. According to Wierzbicka (2003), linguistic distinctions are embodied due to cultural aspects that seem much more effective and powerful than politeness norms in mere form. Meanwhile, these cultural aspects in connecting with cultural distinctions and comprehending of cultural differences which affect communicative behavior is considered as an essential component of intercultural communicative competence (Wierzbicka, 1985, p. 145). Besides, politeness is tightly correlated with the most fundamental principles of interpersonal relationships and sociocultural organization and should be scrutinized in the context of social distance and power distance as two main criteria in per culture. (Guirdham 1999, Hofstede 1991, Haugh \& Chang 2019, Jandt 2003, Larina 2008 \& 2015, Rhee 2019).

Thus, politeness should be understood as a principal aspect of communication, specifically among different cultures, where misunderstanding could cause big destructive effects on relationships in another culture. Due to this fact, in the process of teaching of second language, it endeavors to award the communicative competence to second language learners. Indeed, second language learners would be successful in making communication in SL by understanding limitations in a provided communicative encounter (Tanaka \& Kawade, 1982).

In the present study, we aimed at highlighting how the British and Persian understanding of politess and polite behavior is varied and how cultural values in British and Persian cultures pilot communicative behavior and form the style of interpersonal interactions in family setting. This article has been mainly focused on studying of family discourse and analyzing the norms and politeness strategies in the speech act of response to request in British and Persian family context. The paper is initiated with reviewing some theories of politeness, pragmatics of politeness, politeness and values in British and Persian culture and continued with presenting some results of our practical research concentrated on British and Persian politeness strategies and their effects on everyday interactions in family setting.

\section{PRAGMATICS OF POLITENESS}

Pragmatics, as a subcategory of linguistics and semiotics, delves into the approaches through which context give contribution to meaning. Indeed, pragmatics includes the study of the connections of situational factors to intentions of utterers and real speeches of utterers (Richards, Platt, \& Weber, 1985). According to Cook, pragmatics is how individuals develope meaning and make sense of what is stated in particular situations (Cook, 1989). Meanwhile, Leech believes that pragmatics is the study of meaning in connection with utterance circumstances (Leech, 1983). On the other hand, Levinson debates extensively about available definitions of pragmatics. He drwas the popular notion under criticism that pragmatics deals with the "appropriate" combination of sentences and contexts. From his attitude, this criticism is reasonable due to noticeable overlapping of this definition of pragmatics with sociolinguistics and it is unable to bring an explanation for so-called inappropriate behavior. He insists on Gazdar's opinion based on which pragmatics could bring an appropriate explanation for meaning in approaches that semantics is unable to explain it appropriately (Gazdar, 1979).

Politeness specifies the behavioral style of people. Therefore it is studied in interdisciplinary reasearches 
which discloses the reason and motivation of debating about politeness in connection with pragmatics. Although, politeness is considered as an essential element and controversial debate in communication and culture, but based on numerous concepts in pragmatics, it is not easy to give description for politeness. Green believes that when we discuss on politeness within pragmatics, indeed, we launch to move towards strategies in order to sustain or modify our interpersonal relationships (Green, 1989). In other expressions, politeness in pragmatics is relatively different from people's everyday comprehension of politeness and paying unique attention to polite language in the study of verbal language (Watts, 2003, p. 10). In general, behaving politely encompasses taking peoples' feelings and thoughts into consideration and being aware of people's feeling. Meanwhile, in particular, behaving politely, from linguistics perspective, involves speaking to people in an appropriate way in the right spot and right time. Indeed, people must know the context of speaking because politeness in specific area is different from other areas. (Noviani, 2014)

Yule explaines pragmatics as the study which concentrates on the meaning as conveyed by a utterer and understood by a hearer. This field of study specifically encompasses the understanding of what people want to say in a specific context and how the context affect what is conveyed through utterances (Yule, 1996, p. 3). Meanwhile, Grundy expresses that pragmatics is the study in which is debated how to make utterances and understand what people mean in everyday conversation, although they probably speak in an unaccustomed language (Grundy , 2000, p. 3). Indeed, in pragmatics, politeness is dealt with the approaches through which the relational function is elicited in linguistic action (Kasper \& Rose, 2003). It is also dealt with how language is applied in a strategic approach to achieve such targets as supporting or sustaining interpersonal relationships. Politeness includes how people can give others more pleasant feelings. It also involves the appropriate linguistic selection according to a specific and fixed social as well as situational context (Noviani, 2014). One of the main problems of communication is caused by the fact that understanding of politeness as well as norms of politeness vary across cultures (see Blum-Kulka 1989 \&1992, Hickey \& Stewart 2005, Larina 2008 \& 2015, Locher \& Larina 2019, Mugford 2020, Pizziconi 2003, Sifianou 1992, Tzanne \& Sifianou 2019, Watts 2003 among many others).

\section{UNDERSTANDING OF POLITENESS}

\subsection{Politeness and Values in British Culture}

As our previous study of cultural values and politeness strategies in British and Persian family discourse shows most of the British believe in the following values as the criteria of being polite (Kamehkhosh \& Larina, 2020):

1) having respectful manners and words towards people

2) keeping distance from people and respecting people's privacy

3) respecting to independency of people and their personal autonomy

4) respecting to people's equality of rights

5) acting reserved

6) respecting to what other people feel and think

Our research leads us to this fact that the British emphasize apparantly on "showing respect to other people" or "treating people with honor" as the most highlighted definitions of politeness. Numorous definitions presented by British people, e.g. "having a respectful behavior and manner to people" [F/52/London/secretary], "respecting people" [M/41/London/general manager],"showing good behavior and manner to people" [F/31/London/accountant], "treating with respect to others" [F/40/London/police officer], and "showing a high regard for people" [F/23/London/student], could be considered as outstanding implications of the British dominant attitude of politeness in this culture.

Based on our findings, many British people believe that politeness is "respecting to privacy of people" [M/32/London/Lawyer], "keeping distance from others" [25/F/London/programmer] and "respecting people's personal space" [43/F/London/ laboratory expert]. It means that ignoring people's privacy or breaking distance with others are absolutely impolite in British culture.

Besides, from the British attitudes, "respecting to independency and personal autonomy of people" is also an emphasized definition of politeness in this culture. Meanwhile, this definition concurs partially with the other given definition of politeness as "respecting to people's privacy". According to our research, offering someone in order to keep him / her company or giving an assisting hand to someone to do something together, in some situations, might be perceived by British people as an impolite behavior. 
Our data indicates that "respecting to equality of rights" or "respecting to equality of privileges" among different social classes is definition of politeness from some of the British perspectives. This type of definition of politeness portrays one of the most significant cultural values in this culture. Therefore, the British understanding of politeness is deeply correlated with "respecting people and their individual and social rights".

In our findings, this fact is appeared that another specificity of British politeness refers to emotions in making communication. A number of British peopel believe that politeness is "being reserved" [M/60/London/mass media expert] and "behaving conservatively" [F/26/London/nurse]. Some others define politeness more precisely as "being reserved in presenting opinions" [M/22/London/student] or "being reserved in expressing agreements and/or disagreements" [F/31/London/ marketing manager]. Thus, their definition of politeness is mainly focused on "being reserved" and "treating people conservatively in expressing opinions, agreements or disagreements". Furthermore, they emphasize that keeping their personal feelings hidden and NOT expressing their emotions in public are as important characteristics of polite behavior in British culture [M/27/London/computer engineer]. Some others speculate that politeness is "being considerate of other people" [M/28/London/student] or "being considerate of people's feelings, concerns and thoughts" [F/43/London/laboratory specialist].

As a conclusion, our study approves that the British understanding of politeness is perfectly compatible with their cultural values inlvoving "equality", "independency" and "privacy". Through interpersonal interactions, the British also put high value on honoring "social etiquettes" and "manners" as the most important indications of polite behavior.

\subsection{Politeness and Values in Persian Culture}

Based on our previous study (Kamehkhosh \& Larina, 2020), most of the Persian believe in the following values as the criteria of being polite:

1) respecting elders

2) respecting parents and grandparents

3) honoring teachers and seniors

4) respecting social etiquettes

5) maintaining solidarity and keeping contact with others

6) acting extraverted

Based on our data, the Persian refer to politeness as "respecting to elder people" [M/61/Tehran/doctor] in their most emphasized definitions of politeness. Indeed, their definitions of politeness based on "respecting elder people" [F/20/Tehran/student], "having good behavior and manner with elders" [M/41/Tehran/commercial manager], "honoring elders" [F/32/Tehran/commercial expert] and "holding elders in a high esteem" [M/48/Tehran/financial counsel] could be viewed as an evidence for approving this fact that "respecting elder people" reserves the most influential component of politeness in Persian culture. In other words, in this culture, people emphasize undoubtedly on the importance of "treating elder people with great respect" as a specific indication of politeness. Our findings also approve that "respecting parents and grandparents" [F/44/Tehran/graphist], "having a respectful behavior and manner with parents and grandparents" [F/30/Tehran/dentist] and "holding parents and grandparents in a high regard" $[\mathrm{M} / 25 /$ Tehran/student] have occupied a great part of politeness definitions in Persian culture. .

In Persian culture, persons in a higher standing such as teachers or seniors are highly respected. These findings could be entitled to Muslim culture in general and Persian culture, in particular. The most typical definitions in this regard are "paying a considerable attention and respect to teachers and seniors" [F/20/Tehran/student], "treating teachers and seniors with respect" [F/22/Tehran/photographer] and "being kind and treating respectful with teachers and seniors" [M/61/Tehran/doctor] which put affirmative stamp on this result.

On the other hand, our findings confirm that there is also another highlighted cultural value of politeness in Persian culture which a noticeable number of Persian people have referred to it as "respecting to social etiquettes". Our research indicates that Pesrsian people have their own specific politeness system called "Taarof" based on which they pay lots of compliments to other people, behave courteously and humble to each other, use kind and friendly phrases frequently and treat each other with high respect even in an exaggerated form of respect. 
Furthermore, there is another substantial value in communicative interpersonal interaction as "maintaining solidarity and keeping contact" in Persian culture. The base of relationships in Persian families are constructed on the interdependency principle which is appeared in the form of continuous supporting each other. From the Persian points of view, if someone offers somebody to keep company or extends an assisting hand towards others to proceed something together, it is perfectly polite. It means that, in the Persian opinions, this type of behavioral tendency is an apparent indication of displaying goodwill and respectful feelings towards others.

Meanwhile, the Persian are used to sharing their issues involving problems and achievements with other people as an influential value in this culture. Indeed, they tend willingly to be open and extraverted in their communicative interpersonal encounters. Based on our data, holding weekly gatherings could be viewed as an appropriate evidence for justifying this strong behavioral tendency of the Persian in sharing problems and joyful experiences with others particularly family members. This type of behavior, as an appropriate behavior, happens also in the circle of friends and acquaintances. Our research shows that the result of sharing happiness and joyful experiences with others is granting them the feeling of pride and enjoyment. On the other hand, sharing problems and difficulties with other people, in particular family members, parents and grandparents results in making them aware of the provided situation and trying to get benefit from their pieces of advice in order to remove the problems together.

In conclusion, we might sum up that the Persian understanding of politeness is perfectly compatible with Persian values of "respect to age and status", "solidarity and contact" and "interdependence". Thorough interpersonal interactions, they also value "social etiquettes" as an indication of polite behavior.

\section{DATA AND METHODOLOGY}

This research has been aimed at examining the speech act of response to request which is routinely applied in everyday interactions, analysing the norms and strategies of politeness in British and Persian contexts as well as explaining the norms and strategies of politeness through cultural differences. The data for this analysis was compiled from a questionnaire formed in a structure of DCT (Discourse Completion Task) towards discursive data collection. In this questionnaire, British and Persian objects were given a shortened explanation of eight situations with the specification of the setting and family relationship between the members and they were requested to complete the dialogues of these eight situations in the most natural way which usually take place in family. The questionnaire was designed to extract requesting and response to request. We emailed it to overall 200 native British and Persian people. 55 replies from the British and 57 replies from the Persian returned back. The age of the objects is between $20 \sim 70$ years old. They were British citizens with native English language and Iranian citizens with native Persian language. All the representatives come from middle class of society who have either university degree or are passing university courses. In these cultural categories, we had 31 males (56\%) and 24 females (44\%) among British objects and 17 males (30\%) and 40 females (70\%) among Persian objects.

In this paper, we have merely limited ourselves to the speech act of response to request and the results which we collected drawing on politeness theory (Brown \& Levinson 1987, Leech 2014, Watts 2003), crosscultural pragmatics (Wierzbicka, 2003 \& 1991) and communicative styles theory (Larina 2008, 2009 \& 2015, Leech \& Larina 2014).

\section{RESULTS AND DISCUSSION}

\subsection{Response to Request in British Family}

The theory of face suggested by Brown and Levinson (1987, p. 61) appears as the most important theory on politeness. It plays an influential role in the study of speech acts. This theory involves three basic concepts: face, face threatening acts (FTAs) and politeness strategies. According to Brown and Levinson (ibid. 61), the notion of face is "the public self-image that every member wants to claim for himself". This public self-image consists of two orientations and per individual in society has two types of face wants. One face is negative face that is the fundamental want in order to have territories, personal supporters and a collection of nondistraction's rights. It is the want of every qualified adult individual that his performances be unlimited by others. The other face is positive face that is the positive compatible self-image or personality which is wanted by counteractants. It is the want of every member that his claims be acceptable to at least some other members in society. Each speech is viewed potentially as a face threatening act (FTAs) either to negative or to positive face (Gilks, 2010, Sadeghoghli \& Niroomand, 2016, p. 31). In the present study, the comparative analysis on the speech act of response to request was performed with drawing on (im)politeness theory, speech act theory, cross-cultural pragmatic and discourse analysis research on 
identity construction and the effect of politeness strategies on communicative styles in British and Persian family discourse was reviewed.

Based on our findings, responses to requests among British and Persian families have disclosed some significant differences. In British families, politeness strategies in responding to requests in top-down context between parents to children are conducted friendly and unofficial as in the situations below in the mother's response to the request of her son for bringing him a glass of water (1-2) and in the father's response to the request of his son for repairing his bike (3-5).

1) Yes, of course. (mother to son)

2) OK. (mother to son)

3) Yes, sure. (father to son)

4) OK, I have it get repaired next week. (father to son)

5) This week, I am up to my neck in work, but in a week, I will find free time to repair it. (father to son)

Meanwhile, in British families, politeness strategies in responding to requests in bottom-up context between children to parents are made friendly and unofficial as in the following situation in the daughter's response to the request of her father for passing him the salt at dinner table (6-7). According to our data, in British families, strategies of politeness in responding to requests between children to parents could be also formulated in the form of posing an offer or even refusing the request as in the situations below in the son's response to the request of his father in order to clean the garage (8) and in the daughter's response to the request of her mother for babysitting her sibling (9).

6) Yes, of course. (daughter to father)

7) OK. (daughter to father)

8) Not this week, Dad. But next week. Is it OK? (son to father)

9) I am so sorry, Mom. I have to study for final exam at weekend. (daughter to mother)

\subsection{Response to Request in Persian Family}

Meanwhile, the forms of responding to requests among Persian families is strongly dependent on the context. According to our findings as well as our ethnographic observations, politeness strategies in responding to requests in Persian families in top-down context between parents to children are conducted friendly and unofficial as in the situations below in the mother's response to the request of her son for bringing him a glass of water (10-11) and in the father's response to the request of his son for repairing the bike (12-13).

10) OK. (mother to son)

(bashe.)

11) Yes, of course. (mother to son)

(bale, albate.)

12) OK, I repair it on weekends. (father to son)

$$
\text { باثه، اين آخر هفته تعميرش ميكنم. }
$$

(bashe, in akhare hafte ta-miresh mikonam.)

13) I am busy these days, but I try to look at it at the earliest time. (father to son)

$$
\text { من اين روز ها سرم شلو غه، اما سعى ميكنم در اسرع وقت نكاهى بهش بندازم. }
$$

(man in rooz-ha saram sholooghe, ama say mikonam dar asra-e vaght negahi behesh bendazam.)

However, in Persian families, politeness strategies in responding to requests in bottom-up context between children to parents are conducted in an emphatic polite manner as in the following situations, when the 
daughter responds to the request of her father for passing him the salt at dinner table (14), when the daughter responds to the request of her mother in order to babysit her sibling (15-16) and when the son responds to the request of his father for cleaning the garage (17).

14) Sure, here you are. (daughter to father)

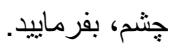

(chashm, befarmayid.)

15) Mom, I wanted to go out with my friends this weekend, but It's OK. I could put it off for a week. (daughter to mother)

$$
\text { مامان من مى خواستم اين آخر هفته با دوستام برم بيرون، اما انشكالى نداره. مى تونم برنامه رو به هفته بعد موكول كنم. }
$$

(maman man mikhastam in akhare hafte ba doostam beram biroon, ama eshkali nadare, mitoonam barnamaro be hafteye ba-d mo-kool konam.)

16) Sure, Mom. I do. (daughter to mother)

(chashm, maman. hatman inkaro mikonam.)

17) Sure, I do. (son to father)

$$
\text { جشم، انجام ميدم. }
$$

(chashm, anjam midam.)

Our findings approve that in responding to parents' requests, Persian children in comparison with their British counterparts manifest less independence and more obedience to their parents. They are permanently interested in bringing immediate reaction to their parents' requests instead of debating about or ignoring it. Based on our results, Persian children would perform their parents' requests with minimum interval and hesitation rather than dealing with their own affairs. In other words, they give priority to requests of their parents and apply too often the word "chasm" which is an affirmative polite word in Persian language for expressing respect and obedience to someone as soon as responding to his/her request(s) without reluctance and uncertainty.

\section{CONCLUSIONS}

The aim of the present study was examining the speech act of response to request which is frequently performed in our everyday interpersonal interactions. We endeavoured to analyse the norms and strategies of politeness in British and Persian contexts and explore these norms and strategies through cultural differences in British and Persian family discourse.

Discursive analysis of everyday encounters in family setting granted us a lot of impressive results which affirm this fact that people are directed by their cultural values and understanding of politeness through their communicative behavioral strategies (Kamehkhosh \& Larina, 2020).

In this paper we have limited ourselves to the speech act of response to request in family setting. Our data explores, since strategies of politeness in top-down (parents to children) and bottom-up (children to parents) contexts in British families are conducted perfectly egalitarian, therefore, the behavioral strategies of parents towards children and children towards parents in responding to request are also made friendly and unofficial in these both contexts as mentioned in examples. These results confirm a low power index in British society (Hofstede, 1991). By contrast, as there are significant distinctions in politeness strategies of responding to request in top-down context between parents to children and bottom-up context between children to parents in Persian families, therefore, we could conclude that there is a considerable power distance in Persian society. Indeed, in Persian families, strategies of politeness in responding to request in bottom-up context is conducted in an empathic polite manner and children respond to the request of their parents with minimum interval and hesitation. Meanwhile, politeness strategies in responding to request in top-down context between parents to children are performed friendly and unofficial. This type of behavioral tendency in Persian culture descends from Persian religion and belief based on which parents are to be highly respected and appreciated.

Consequently, we could mention that in different societies and communities, people make communication and speak to each other in distinctive approaches and these distinctions in approaches of speaking, as vital 
and systematic elements could be able to reflect different cultural values or different hierarchies of values. In other expressions, different approaches of speaking as well as different styles of making communication could be defined and made sense in terms of different cultural values and cultural priorities which have been established independently (Wierzbicka, 2003 \& 1991).

\section{REFERENCE LIST}

Blum-Kulka, S. (1989). Cross-cultural pragmatics: Requests and apologies. In S. Blum-Kulka, J. House, \& G. Kasper (Eds.), Playing it Safe: The Role of Conventionality in Indirectness (pp. 37-70). Norwood: Ablex Publishing Corporation.

Blum-Kulka, S. (1992). The metapragmatics of politeness in Israeli society*. In R. J. Watts, S. Ide, \& K. Ehlich (Eds.), Politeness in Language: Studies in its History, Theory and Practice (pp. 255-280). Berlin, Germany \& New York, USA: Mouton de Gruyter.

Brown, P., \& Levinson, S. C. (1987). Politeness: Some Universals in Language Usage. (J. J. Gumperz, Ed.) New York, USA: Cambridge University Press: Press Syndicate of the University Of Cambridge.

Cook, G. (1989). Discourse. Oxford, UK: Oxford University Press.

Gazdar, G. (1979). Pragmatics: Implicature, Presuppositions and Logical Form. New York, USA: Academic Press.

Gilks, K. (2009-2010). Is the Brown and Levinson (1987) model of politeness as useful and influential as originally claimed? An assessment of the revised Brown and Levinson (1987) model. INNERVATE: Leading Undergraduate Work in English Studies, Volume 2, 94-102.

Green, G. (1989). Pragmatics and natural language understanding. Language, Volume 67, Issue No. $2,345-$ 347.

Grundy , P. (2000). Doing Pragmatics. London, UK: Arnold.

Guirdham, M. (1999). Communicating across cultures. In T. V. Larina, Intercultural Communication: Theory and Practice, How cultures differ: Explanation of cultural differences (pp. 48-52). London, UK: Palgrave.

Haugh, M., \& Chang, W.-L. M. (2019). Indexical and sequential properties of criticisms in initial interactions: Implications for examining (im)politeness across cultures. Russian Journal of Linguistics, Volume 23, No. 4, 904-929. doi:10.22363/2312-9182-2019-23-4-904-929

Hickey, L., \& Stewart, M. (2005). Politeness in Europe. Clevedon/Buffalo/Toronto: Multilingual Matters Ltd.

Hofstede, G. (1991). Cultures and Organizations: Software of the Mind. Limburgat Maastricht, The Netherlands: The McGraw-Hills Companies.

Jandt, F. (2003). An introduction to intercultural communication: Identities in a global community. In T. V. Larina, Intercultural Communication: Theory and Practice, Communication as an element of culture (4th ed., pp. 29-32). California, USA: Sage.

Kamehkhosh, N., \& Larina, T. V. (2020). Cultural values and politeness strategies in British and Persian family discourse. Proceedings of INTCESS 2020: 7th International Conference on Education and Social Sciences , 603-610.

Kasper, G., \& Rose, K. R. (2003). Pragmatic development in a second language. (R. F. Young, Ed.) Language Learning: A Journal of Research in Language Studies.

Larina, T. V. (2008). Directness, imposition and politeness in English and Russian. Cambridge ESOL Research Notes 33, 33-38.

Larina, T. V. (2015). Culture-specific communicative styles as a framework for interpreting linguistic and cultural idiosyncrasies*. BRILL: International Review of Pragmatics 7, 195-215.

Leech, G. (1983). Principles of Pragmatics. New York, USA: Longman.

Leech, G. (2014). The Pragmatics of Politeness. New York, USA: Oxford University Press. 
Leech, G., \& Larina, T. V. (2014). Politeness: West and East. Russian Journal of Linguistics, No.4, 9-34.

Levinson, S. C. (1983). Pragmatics. Cambridge, UK: Cambridge University Press.

Locher, M. A., \& Larina, T. V. (2019). Introduction to politeness and impoliteness research in global contexts. Russian Journal of Linguistics, Volume 23, No. 4, 873-903. doi:10.22363/2312-9182-2019-23-4-873903

Mugford, G. (2020). Mexican politeness: An empirical study on the reasons underlying/motivating practices to construct local interpersonal relationships. Russian Journal of Linguistics 24(1), 31-55.

Noviani, Q. (2014). A pragmatic analysis of politeness strategies and politeness principles in Uptown Girls. Depok, Indonesia: Yogyakarta State University.

Pizziconi, B. (2003). Re-examining politeness, face and the Japanese language. Journal of Pragmatics, 35, 1471-1506.

Rhee, S. (2019). Politeness pressure on grammar: The case of first and second person pronouns and address terms in Korean. Russian Journal of Linguistics 23 (4), 950-974. doi:10.22363/2312-91822019-23-4-950-974

Richards, J. C., Platt, J., \& Weber, H. (1985). Longman Dictionary of Applied Linguistics. London, UK: Harlow, Essex, England: Longman.

Sadeghoghli, H., \& Niroomand, M. (2016). Theories on politeness by focusing on Brown \& Levinson's politeness Theory. International Journal of Educationl Investigations (online) Volume 3, No. 2, 26-39.

Sifianou, M. (1992). Politeness phenomena in England and Greece: A cross-cultural perspective. Journal of Pragmatics 22, 227-232.

Tanaka, S., \& Kawade, S. (1982). Politeness strategies and second language acquisition. Studies in Second Language Acquisition 5, No. 1, 18-33.

Tzanne, A., \& Sifianou, M. (2019). Understanding of impoliteness in Greek contexts. Russian Journal of Linguistics, Volume 23, No. 4, 1014-1038. doi:10.22363/2312-9182-2019-23-4-1014-1038

Watts, R. J. (2003). Politeness. Cambridge, UK: Cambridge University Press: Press Syndicate of the University of Cambridge.

Watts, R. J., Ide, S., \& Ehlich, K. (2005). Introduction. In Politeness in Language: Studies in its History, Theories (p. 3). Berlin.New York: Mouton de Gruyter: Walter de Gryuter GmbH \& Co. KG Berlin.

Wierzbicka , A. (1985). Different cultures, different languages, different speech acts: Polish vs. English. ScienceDirect: Journal of Pragmatics, Volume 9, Issues 2-3, 145-178.

Wierzbicka, A. (2003 \& 1991). Cross-Cultural Pragmatics: The Semantics of Human Interaction (2nd ed.). Berlin, Germany \& New York, USA: Mouton de Gruyter.

Yule, G. (1996). Pragmatics. (H. G. Widdowson, Ed.) Oxford, UK: Oxford University Press. 